\title{
Evaluation of Green Long Pre-Breeding Lines of Brinjal (Solanum melongena L.) for Bacterial Wilt Resistance, Yield and Yield Attributing Traits
}

\author{
Neelambika $^{1^{*}}$, H.B. Lingaiah ${ }^{2}$, Jyothi Kattegoudar ${ }^{1}$, S.J. Prashanth ${ }^{3}$, \\ T.H. Singh ${ }^{3}$ and Amruta S. Bhat ${ }^{4}$
}

${ }^{1}$ Department of Vegetable Science, ${ }^{4}$ Department of Plant Pathology, College of Horticulture, UHS campus, GKVK (PO), Bengaluru 560065, India

${ }^{2}$ University of Horticulture Science, Navanagar, Bagalkot 587104, India

${ }^{3}$ Division of Vegetable Science, IIHR, Hesarghatta, Ivar Kandapura, Bengaluru 560069, India

*Corresponding author

\section{A B S T R A C T}

Keywords

Bacterial wilt,

Inoculation, Pre-breeding

lines, Segregating lines, Brinjal

Article Info

Accepted:

10 July 2018

Available Online:

10 August 2018
Ten pre-breeding lines of $\mathrm{F}_{4}$ generation green long brinjal of Green Long x IIHR-3 along with their parents and checks (Arka Anand and Arka Kusumakar) were evaluated for bacterial wilt resistance after artificial inoculation and good horticultural properties. The results revealed that among 10 families of $\mathrm{F}_{4}$ lines derived from the cross Green Long x IIHR-3 the progenies viz., 12-36-164-7, 1236-164-10, 12-36-164-11 and 12-36-164-14 showed moderate resistance to the bacterial wilt disease, whereas, 12-36-46-3, 12-36-46-6, 12-36-164-1, 12-36-1709, 12-36-170-11 and 12-36-170-19 found to be resistance. $\mathrm{F}_{4}$ pre-breeding lines had shown a larger extent of variation for all the traits when compared to the interfamily variation, so there is a need of further advancement of generation to attain the homozygosity. The study lead to identification of superior green round brinjal plants resistant to bacterial wilt along with good horticultural properties from $\mathrm{F}_{3: 4}$ segregating population.

\section{Introduction}

One of the most important solanaceous vegetable crop grown worldwide is brinjal or eggplant (Solanum melongena L.), which can be grown easily year round in tropical and sub-tropical regions except in higher altitudes where it is susceptible to frost injury. Brinjal is a rich source of vitamins and minerals, but their production is hindered by many biotic and abiotic stresses. Among biotic stresses, bacterial wilt is one of the most devastating diseases. It is caused by the gram negative bacterium Ralstonia solanacearum (Smith), previously known as Pseudomonas solanacearum (Smith) leading to yield loss ranging from 4.24 to 86.14 per cent (Sabita et al., 2000). There are different sources of bacterial wilt disease resistant species have 
been identified like, $S$. melongena, S. torvum, S.sisymbrifolium, $S$. aethiopicum, $S$. xanthocarpum, S. toxicarum and $S$. nigrum (Kalloo, 1994). The bacterium enters the plant through wounded roots and progressively invades the stem vascular tissues, leading to a sudden wilting. The affected stem shows vascular discoloration which may be accompanied by browning and rotting of tissues inside the vascular bundles. Even though there are various cultural, biological and chemical control measures have been suggested for the management of bacterial wilt incidence, these are found to be less effective. It is a complex interaction between the environment, pathogen strains and host plants. Even though there are various varieties in purple fruited segment of brinjal, modern technologies and voluminous literature have been reported, still there is a need to concentrate more on development of broad spectrum bacterial wilt disease resistance to select and identify stable resistant cultivars along with good horticultural properties in green long segment of Brinjal. This study was undertaken with an aim to select superior recombinant for bacterial wilt resistance from $\mathrm{F}_{3: 4}$ pre-breeding lines of Green Long x IIHR3.

\section{Materials and Methods}

The experiment which was been conducted with the objective of estimating resistance in pre-breeding lines of green long brinjal (Solanum melongena L.). This experiment was conducted at College of Horticulture, ten $\mathrm{F}_{3: 4}$ pre-breeding lines of Green Long x IIHR-3 namely, 12-36-46-3, 12-36-46-6, 12-36-164-1, 12-36-164-7, 12-36-164-10, 12-36-164-11, 12-36-164-14, 12-36-170-9, 12-36-170-11 and 12-36-170-19 along with their susceptible and resistant parents viz., Green Long and IIHR-3 respectively with resistant check Arka Anand and susceptible check Arka Kusumakar were evaluated in the field for bacterial wilt disease resistance and horticultural properties. The Ralstonia solanacearum (Smith) inoculums were prepared from the bacterial colonies obtained from freshly wilted brinjal plants as prescribed by Kelman (1954). $R$. Solanacearum (Smith) suspension of concentration $1.0 \times 10^{6} \mathrm{cfu} / \mathrm{ml}$. About $5.0 \mathrm{ml}$ of bacterial suspension was inoculated to each of the seedling. Before inoculation, the roots were slightly damaged by inserting a sharp knife $1.0 \mathrm{~cm}$ away from the stem then inoculums was drenched around the root zone on $21^{\text {st }}$ day of sowing. Then during transplanting also seedlings were dipped in the bacterial suspension and planted in the main field. Data on death of the plants due to bacterial wilt disease incidence was taken until the end of the cropping season (four harvests). Occurrence of bacterial wilt was confirmed by conducting bacterial ooze test on wilted plants. The percentage of wilted plants in each line was calculated by using the following formula.

Per cent disease incidence $(\mathrm{PDI})=$ Number of plants infected with bacterial wilt / Total number of plants $* 100$

Further, genotypes were classified into five different groups as given below according to percent disease incidence as reported by Hussain et al., (1952).

\section{Results and Discussion}

The evaluation results revealed that the parent Green Long and the check Arka Kusumakar were highly susceptible with bacterial wilt disease incidence of 90.28 per cent and 91.67 per cent respectively. The resistant parent and check like IIHR-3 and Arka Anand respectively showed very less disease incidence i.e., 20.00 per cent and 4.16 per cent respectively (Table 2). Among 10 families of $\mathrm{F}_{4}$ lines derived from the cross Green Long $\mathrm{x}$ IIHR-3 the progenies viz., 12-36-164-7 
(46.66\%), 12-36-164-10 (30.00\%), 12-36-164$11(27.50 \%)$ and $12-36-164-14 \quad(27.50 \%)$ showed moderate resistance to the bacterial wilt disease, whereas, 12-36-46-3, 12-36-46-6, 12-36-164-1, 12-36-170-9, 12-36-170-11 and 12-36-170-19 found to be resistance to bacterial wilt with a percent disease incidence of 10.00 per cent, 20.00 per cent, 17.50 per cent, 17.50 per cent, 7.40 per cent and 12.50 per cent respectively. This may be due to the presence of polyphenolic compound or glycoalkaloids in resistant lines Vasse et al., 2005. This result was in accordance with Hussain et al., (2005).

Means and standard deviation of various quantitative characters for pre-breeding lines their parents and checks are presented in the Table 3 and 4 respectively. Out of ten $F_{4}$ families none of them had shown highest plant height when compared to the parent and checks among these lines highest plant height had shown in the line 12-36-170-11(51.63 cm) with a range of $37.00 \mathrm{~cm}$ to $70.00 \mathrm{~cm}$ and lowest was noticed in the line 12-36-164-7 $(40.17 \mathrm{~cm})$.

Highest mean value foe number of branches was observed in line 12-36-170-11 (7.71) with a range of 4 to 11 followed by 12-36-1164-11 (7.28) and lowest was noticed in line 12-3646-3 (5.61). None of the pre-breeding lines showed lesser mean number of days for first flowering than the parents, but there are plants within each lines which showed early bearing habit. Higher values of standard deviation were observed for average fruit weight in all the pre-breeding lines which indicates more deviation from the mean value for this character. The wider range of variation in the fruit length, fruit breadth and average fruit weight may be due to the variation in the maturity stages of fruits harvested at each picking. The line 12-36-46-3 had shown highest mean value for average fruit weight $43.50 \pm 10.89$ with a range of $24.33 \mathrm{~g}$ to $72.00 \mathrm{~g}$ followed by 12-36-46-6 (38.58 \pm 11.36$)$ while, lowest was observed in line 12-36-164-7 $(30.93 \pm 7.91)$. All the pre-breeding lines were recorded with more average number of fruits per plant and yield per plant compared to both of the parents where, highest was noticed in the line 12-36-170-19 (13.07 \pm 9.74$)$ with a range of 2.00 to 47.00 fruits per plant and highest fruit yield per plant was found in line 12-36-164-11 (405.18 $\pm 371.83 \mathrm{~g})$ when compared to both the parents (Table 3 and 4). A wide range of variation exists for almost all the quantitative characters in the pre-breeding lines of brinjal. These results are in accordance with Prasad et al., (2006), Kumar et al., (2011), Madhavi et al., (2015) and Patel et al., (2017).

Table.1 Disease reaction index

\begin{tabular}{|l|l|}
\hline Disease reaction & Per cent wilt incidence \\
\hline Highly resistant (HR) & Plants do not show any wilt symptom \\
\hline Resistant (R) & $1-20 \%$ plants wilt \\
\hline Moderately resistant (MR) & 21-40\% plants wilt \\
\hline Moderately susceptible (MS) & $41-60 \%$ plants wilt \\
\hline Susceptible (S) & $61-80 \%$ plants wilt \\
\hline Highly susceptible (HS) & More than $80 \%$ plants wilt \\
\hline
\end{tabular}


Table.2 Reactions of $\mathrm{F}_{3: 4}$ pre-breeding lines of Green Long x IIHR-3, their parents and checks to Ralstonia solanacearum (Smith)

\begin{tabular}{|c|c|c|c|c|c|}
\hline $\begin{array}{l}\text { Sl. } \\
\text { No. }\end{array}$ & $\begin{array}{l}\text { Line } \\
\text { number/Parents/Checks }\end{array}$ & Percentage & Reaction & Incubation & $\begin{array}{l}50 \% \\
\text { wilt }\end{array}$ \\
\hline & & wilt & & $\begin{array}{l}\text { period } \\
\text { (Days) }\end{array}$ & on DAT \\
\hline 1 & $12-36-46-3$ & 10.00 & $\mathrm{R}$ & 58 & - \\
\hline 2 & $12-36-46-6$ & 20.00 & $\mathrm{R}$ & 59 & - \\
\hline 3 & $12-36-164-1$ & 17.50 & $\mathrm{R}$ & 35 & - \\
\hline 4 & $12-36-164-7$ & 46.66 & MS & 36 & - \\
\hline 5 & $12-36-164-10$ & 30.00 & MR & 34 & - \\
\hline 6 & $12-36-164-11$ & 27.50 & MR & 34 & - \\
\hline 7 & $12-36-164-14$ & 27.50 & MR & 34 & - \\
\hline 8 & $12-36-170-9$ & 17.50 & $\mathrm{R}$ & 34 & - \\
\hline 9 & $12-36-170-11$ & 7.40 & $\mathrm{R}$ & 46 & - \\
\hline 10 & $12-36-170-19$ & 12.50 & $\mathrm{R}$ & 48 & - \\
\hline 11 & Green Long & 90.28 & HS & 25 & 53 \\
\hline 12 & IIHR-3 & 20.00 & $\mathrm{R}$ & 30 & - \\
\hline 13 & Arka Anand & 4.16 & $\mathrm{R}$ & 34 & - \\
\hline 14 & $\begin{array}{l}\text { Arka } \\
\text { Kusumakar }\end{array}$ & 91.67 & HS & 21 & 52 \\
\hline
\end{tabular}

$\mathrm{R}$ - resistant $\mathrm{MR}$ - moderately resistant; $\mathrm{MS}$ - moderately susceptible HS - highly susceptible; DAT - Days after transplanting 
Table.3 Mean and standard deviations of various quantitative characters for ten pre-breeding lines of Green Long and IIHR-3

\begin{tabular}{|c|c|c|c|c|c|c|c|c|c|}
\hline \multirow[b]{2}{*}{ Genotype } & \multicolumn{2}{|c|}{$12-36-46-3$} & & \multicolumn{2}{|c|}{$12-36-46-6$} & & \multicolumn{2}{|c|}{$12-36-164-1$} & \\
\hline & \multirow{3}{*}{ Mean \pm SD } & \multicolumn{2}{|l|}{ Range } & & \multicolumn{2}{|l|}{ Range } & & \multicolumn{2}{|l|}{ Range } \\
\hline & & Min & Max & Mean \pm SD & Min & Max & Mean \pm SD & Min. & Max \\
\hline \multicolumn{9}{|l|}{ Characters } & \\
\hline Plant height $(\mathrm{cm})$ & $46.73 \pm 11.42$ & 29.00 & 75.00 & $45.92 \pm 8.48$ & 32.00 & 65.00 & $42.92 \pm 8.79$ & 24.00 & 65.00 \\
\hline No. of branches/ plant & $5.61 \pm 1.84$ & 4.00 & 12.00 & $6.36 \pm 2.43$ & 4.00 & 12.00 & $6.15 \pm 1.97$ & 4.00 & 12.00 \\
\hline Days to first flowering & $47.00 \pm 4.63$ & 36.00 & 55.00 & $43.32 \pm 4.64$ & 34.00 & 54.00 & $46.23 \pm 6.38$ & 31.00 & 54.00 \\
\hline Average fruit weight (g) & $43.50 \pm 10.89$ & 24.33 & 72.00 & $38.58 \pm 11.36$ & 7.35 & 67.16 & $33.30 \pm 10.79$ & 18.41 & 75.80 \\
\hline Fruit length $(\mathrm{cm})$ & $10.95 \pm 1.62$ & 7.50 & 14.00 & $10.37 \pm 1.39$ & 7.00 & 12.50 & $10.70 \pm 1.85$ & 8.00 & 16.00 \\
\hline Fruit breadth $(\mathrm{cm})$ & $1.77 \pm 0.47$ & 1.15 & 2.9 .00 & $1.76 \pm 0.51$ & 1.20 & 3.40 & $1.40 \pm 0.34$ & 0.90 & 2.30 \\
\hline No. of fruits/plant & $6.64 \pm 3.93$ & 2.00 & 16.00 & $9.72 \pm 7.87$ & 3.00 & 41.00 & $8.85 \pm 4.16$ & 3.00 & 18.00 \\
\hline Yield/ plant (g) & $274.91 \pm 158 . .35$ & 100.00 & 666.00 & $336.74 \pm 198.72$ & 103.00 & 844.00 & $274.14 \pm 98.89$ & 111.00 & 436.00 \\
\hline
\end{tabular}

\section{Continued...}

\begin{tabular}{|c|c|c|c|c|c|c|c|c|c|}
\hline \multirow[b]{2}{*}{ Genotype } & \multicolumn{2}{|c|}{$12-36-164-7$} & & \multicolumn{2}{|c|}{ 12-36-164-10 } & & \multicolumn{2}{|c|}{ 12-36-164-11 } & \\
\hline & \multirow[b]{2}{*}{ Mean $\pm \mathrm{SD}$} & \multicolumn{2}{|l|}{ Range } & & \multicolumn{2}{|l|}{ Range } & & \multicolumn{2}{|l|}{ Range } \\
\hline & & Min & $\operatorname{Max}$ & Mean \pm SD & Min & Max & Mean \pm SD & Min. & Max \\
\hline \multicolumn{10}{|l|}{ Characters } \\
\hline & $40.17 \pm 7.86$ & 30.00 & 58.00 & $46.90 \pm 9.02$ & 28.00 & 63.00 & $51.41 \pm 10.27$ & 21.00 & 70.00 \\
\hline \multicolumn{10}{|l|}{ Plant height $(\mathrm{cm})$} \\
\hline No. of branches/ plant & $6.06 \pm 1.84$ & 4.00 & 10.00 & $6.21 \pm 2.01$ & 4.00 & 11.00 & $7.28 \pm 2.72$ & 4.00 & 16.00 \\
\hline Days to first flowering & $47.31 \pm 5.56$ & 39.00 & 56.00 & $44.72 \pm 4.35$ & 38.00 & 54.00 & $47.10 \pm 5.23$ & 38.00 & 54.00 \\
\hline Average fruit weight (g) & $30.93 \pm 7.91$ & 18.41 & 48.96 & $38.11 \pm 7.31$ & 26.71 & 50.33 & $35.94 \pm 10.39$ & 22.25 & 71.66 \\
\hline Fruit length $(\mathrm{cm})$ & $10.37 \pm 1.54$ & 8.30 & 13.75 & $10.26 \pm 1.74$ & 8.00 & 14.50 & $11.12 \pm 2.08$ & 5.00 & 14.25 \\
\hline Fruit breadth $(\mathrm{cm})$ & $1.29 \pm 0.23$ & 0.95 & 1.86 & $1.50 \pm 0.24$ & 1.10 & 2.06 & $1.48 \pm 0.29$ & 0.95 & 2.00 \\
\hline No. of fruits/plant & $8.13 \pm 1.75$ & 5.00 & 11.00 & $8.86 \pm 4.75$ & 3.00 & 20.00 & $9.55 \pm 3.86$ & 4.00 & 16.00 \\
\hline Yield/ plant (g) & $290.81 \pm 103.41$ & 132.00 & 436.00 & $325.53 \pm 165.34$ & 128.00 & 694.40 & $405.18 \pm 371.83$ & 130.00 & 2160.00 \\
\hline
\end{tabular}




\section{Continued...}

\begin{tabular}{|c|c|c|c|c|c|c|c|c|c|c|c|c|}
\hline \multirow{3}{*}{$\begin{array}{l}\text { Genotype } \\
\text { Characters }\end{array}$} & \multicolumn{2}{|c|}{$12-36-164-14$} & & \multicolumn{2}{|c|}{$2-36-170-9$} & & \multicolumn{2}{|c|}{ 12-36-170-11 } & & \multicolumn{2}{|c|}{$12-36-170-19$} & \\
\hline & \multirow[b]{2}{*}{ Mean \pm SD } & \multirow{2}{*}{$\begin{array}{l}\text { Range } \\
\text { Min. }\end{array}$} & \multirow[b]{2}{*}{ Max } & \multirow[b]{2}{*}{ Mean \pm SD } & \multicolumn{2}{|l|}{ Range } & \multirow[b]{2}{*}{ Mean \pm SD } & \multicolumn{2}{|l|}{ Range } & \multirow[b]{2}{*}{ Mean \pm SD } & \multirow[b]{2}{*}{ Min. } & \multirow{2}{*}{$\begin{array}{l}\text { Range } \\
\text { Max }\end{array}$} \\
\hline & & & & & Min. & Max & & Min. & Max & & & \\
\hline Plant height $(\mathrm{cm})$ & $47.30 \pm 8.71$ & 28.00 & 65.00 & $50.26 \pm 6.55$ & 33.00 & 60.00 & $51.63 \pm 7.33$ & 37.00 & 70.00 & $49.46 \pm 6.98$ & 36.00 & 62.00 \\
\hline No. of branches/ plant & $6.93 \pm 1.88$ & 4.00 & 12.00 & $7.03 \pm 1.49$ & 4.00 & 9.00 & $7.71 \pm 1.53$ & 4.00 & 11.00 & $7.07 \pm 1.84$ & 4.00 & 11.00 \\
\hline Days to first flowering & $45.33 \pm 6.22$ & 31.00 & 54.00 & $47.81 \pm 4.79$ & 40.00 & 55.00 & $47.43 \pm 5.70$ & 38.00 & 54.00 & $45.25 \pm 6.20$ & 30.00 & 54.00 \\
\hline Average fruit weight $(\mathrm{g})$ & $32.98 \pm 10.23$ & 11.44 & 56.00 & $35.65 \pm 9.79$ & 16.66 & 70.23 & $32.49 \pm 7.57$ & 12.07 & 46.53 & $34.07 \pm 10.051$ & 12.20 & 53.50 \\
\hline Fruit length $(\mathrm{cm})$ & $10.23 \pm 2.51$ & 4.10 & 14.80 & $11.48 \pm 1.87$ & 5.00 & 14.50 & $11.33 \pm 1.40$ & 8.50 & 13.80 & $10.89 \pm 2.35$ & 5.10 & 15.10 \\
\hline Fruit breadth $(\mathrm{cm})$ & $1.65 \pm 0.37$ & 1.06 & 2.65 & $1.57 \pm 0.38$ & 1.05 & 2.40 & $1.56 \pm 038$ & 0.90 & 2.35 & $1.51 \pm 0.41$ & 0.95 & 2.66 \\
\hline No. of fruits/plant & $9.78 \pm 7.21$ & 3.00 & 39.00 & $9.90 \pm 6.33$ & 3.00 & 30.00 & $11.83 \pm 6.33$ & 3.00 & 22.00 & $13.07 \pm 9.74$ & 2.00 & 47.00 \\
\hline Yield/ plant (g) & $275.95 \pm 110.31$ & 135.20 & 482.20 & $345.13 \pm 221.34$ & 100.00 & 966.00 & $377.51 \pm 221.34$ & 132.80 & 739.60 & $385.44 \pm 207.60$ & $\begin{array}{c}107.0 \\
0\end{array}$ & 956.80 \\
\hline
\end{tabular}

SD - Standard deviation

Table.4 Mean and standard deviations of various quantitative characters for parents and checks

\begin{tabular}{|c|c|c|c|c|c|c|c|c|}
\hline \multirow[t]{2}{*}{ Parent/ check } & \multirow[t]{2}{*}{ Plant height (cm) } & Number of & Days to first & Average fruit & Fruit length & Fruit breadth & Number of & Yield /plant (g) \\
\hline & & branches & flowering & weight (g) & $(\mathbf{c m})$ & $(\mathbf{c m})$ & fruits/plant & \\
\hline Green Long & $47.80 \pm 1.92$ & $7.20 \pm 0.44$ & $40.2 \pm 1.78$ & $34.53 \pm 2.38$ & $11.93 \pm 0.43$ & $2.10 \pm 0.10$ & $4.40 \pm 0.54$ & $151.10 \pm 12.00$ \\
\hline IIHR-3 & $58.40 \pm 3.36$ & $8.40 \pm 0.54$ & $37.8 \pm 1.78$ & $43.00 \pm 1.46$ & $12.75 \pm 0.43$ & $1.54 \pm 0.14$ & $5.20 \pm 0.54$ & $223.27 \pm 14.75$ \\
\hline Arka Anand & $59.60 \pm 3.05$ & $9.20 \pm 0.84$ & $36.80 \pm 1.48$ & $33.16 \pm 0.89$ & $14.63 \pm 0.45$ & $2.88 \pm 0.24$ & $11.00 \pm 0.71$ & $364.49 \pm 18.97$ \\
\hline Arka Kusumakar & $55.60 \pm 1.67$ & $8.00 \pm 1.22$ & $36.60 \pm 1.14$ & $27.02 \pm 1.81$ & $11.50 \pm 0.73$ & $2.85 \pm 0.22$ & $9.00 \pm 1.00$ & $242.10 \pm 18.49$ \\
\hline
\end{tabular}


Table.5 Quantitative characters of selected individual plants in $\mathrm{F}_{3: 4}$ segregating population

\begin{tabular}{|c|c|c|c|c|c|c|c|c|}
\hline Entry No. & Plant & No. of & Days to & Fruit & Fruit & Total No. & Average & Yield / plant \\
\hline & height & branches & $1^{\text {st }}$ & length & breadth & of fruits/ & fruit weight & (g) \\
\hline & $(\mathrm{cm})$ & & flowering & $(\mathrm{cm})$ & $(\mathrm{cm})$ & plant & (g) & \\
\hline $12-36-46-3-32$ & 65.00 & 7.00 & 45.00 & 10.50 & 1.30 & 9.00 & 24.33 & 219.00 \\
\hline $12-36-46-3-35$ & 52.00 & 8.00 & 42.00 & 12.75 & 1.80 & 12.00 & 41.98 & 503.80 \\
\hline $12-36-46-6-4$ & 51.00 & 9.00 & 43.00 & 11.50 & 1.60 & 5.00 & 46.60 & 233.00 \\
\hline $12-36-46-6-10$ & 46.00 & 12.00 & 43.00 & 11.00 & 1.20 & 15.00 & 39.97 & 599.60 \\
\hline $12-36-46-6-37$ & 45.00 & 6.00 & 45.00 & 9.73 & 1.40 & 4.00 & 50.75 & 203.00 \\
\hline $12-36-170-9-15$ & 55.00 & 6.00 & 44.00 & 10.52 & 1.85 & 30.00 & 32.20 & 966.00 \\
\hline $12-36-170-9-19$ & 52.00 & 9.00 & 43.00 & 13.00 & 1.46 & 15.00 & 33.93 & 509.00 \\
\hline $12-36-170-9-30$ & 58.00 & 9.00 & 44.00 & 12.60 & 1.40 & 13.00 & 31.33 & 407. 40 \\
\hline $12-36-170-11-1$ & 55.00 & 7.00 & 45.00 & 12.00 & 1.10 & 16.00 & 25.53 & 408.60 \\
\hline $12-36-170-11-11$ & 53.00 & 10.00 & 41.00 & 13.60 & 1.16 & 22.00 & 32.96 & 725.20 \\
\hline $12-36-170-11-14$ & 55.00 & 7.00 & 38.00 & 10.80 & 1.60 & 20.00 & 27.75 & 555.00 \\
\hline $12-36-170-19-19$ & 46.00 & 7.00 & 45.00 & 15.10 & 1.70 & 22.00 & 34.33 & 755.40 \\
\hline $12-36-170-19-26$ & 58.00 & 9.00 & 46.00 & 11.47 & 1.93 & 33.00 & 28.99 & 956.80 \\
\hline
\end{tabular}

Considering both bacterial wilt resistance reaction and various quantitative characters the superior plants in the resistant lines12-3646-3, 12-36-46-6, 12-36-170-11, 12-36-170-9 and 12-36-170-19-26 were selected for further evaluation in $\mathrm{F}_{4: 5}$ generation (Table 5).

Further evaluation and selection of superior plants from the segregating generation will lead to the development of bacterial wilt resistant green long brinjal varieties having good horticultural properties.

\section{Acknowledgement}

The author thankful to Dr. H. B. Lingaiah, Vice Chancellor, University of Horticultural Sciences, Bagalkot and Dr. Jyothi Kattegoudar, Asst. Professor, Department of Vegetable Science, College of Horticulture, UHS Campus, GKVK (PO) for endless support during the course of investigation.

\section{References}

Hussain, Z. M., Rahman, M. A. and Bashar, M. A., 2005, Screening of brinjal accessions for bacterial wilt caused by Ralstonia solanacearum. Bangladesh J. Bot., 34 (1): 53-58.

Kallo, G., 1994, Vegetable breeding Combined edition (Volume I, II and III). Panima educational book agency, New Delhi. pp. 90-91.

Kelman, A., 1954. The relationship of pathogenicity in Pseudomonas solanacearum to colony appearance on a tetrazolium medium. Phytopathol., 44: 693-695.

Kumar, A., Kumar, S. and Yadav, Y. C., 2011, Variability studies for yield and yield attributing characters in brinjal (Solanum melongena L.). Prog. Agric., 11(2): 486-488. 
Madhavi, N., Mishra, A. C., Prasad, O. and Bahuguna, N., 2015, Studies on variability, heritability and genetic advance in brinjal (Solanum melongena L.). Pl. Archives., 15(1): 277-281.

Patel, V. K., Singh, U., Goswami, A., Tiwari, S. K. and Singh, M., 2017, Genetic variability, interrelationships and path analysis for yield attributes in eggplant. Environ. Ecol. 35(2A): 877-880.

Prasad, M., Mehta, N. and Nichal, S. S., 2006, Genetic variability, genetic advance and heritability in brinjal (Solanum melongena L.). Pl. Archives, 6(1): 161163.
Sabita, J. N., Boruah, B. M. and Rachid, H. A., 2000, Yield potentiality of some brinjal cultivars in severely bacterial wilt infected condition. Veg. Sci., 27: 76-77.

Vasse, J., Danoun, S. and Trigalet, A., 2005, Microscopic studies of root infection in resistant tomato cultivar Hawaii 7996. In: Allen, C., Prior, P. and Hayward, A.C. (eds.). Bacterial wilt disease and the Ralstonia solanacearum species complex. APS Press, St. Paul, Minnesota, USA, $285 \mathrm{p}$.

\section{How to cite this article:}

Neelambika, H.B. Lingaiah, Jyothi Kattegoudar, S.J. Prashanth, T.H. Singh and Amruta S. Bhat. 2018. Evaluation of Green Long Pre-Breeding Lines of Brinjal (Solanum melongena L.) for Bacterial Wilt Resistance, Yield and Yield Attributing Traits. Int.J.Curr.Microbiol.App.Sci. 7(08): 1650-1657. doi: https://doi.org/10.20546/ijcmas.2018.708.189 